\title{
The effect of the NK2 tachykinin receptor antagonist SR 48968 (saredutant) on neurokinin A-induced bronchoconstriction in asthmatics
}

\author{
J. Van Schoor*, G.F. Joos*, B.L. Chasson+, R.J. Brouard+, R.A. Pauwels*
}

\begin{abstract}
The effect of the NK2 tachykinin receptor antagonist SR 48968 (saredutant) on neurokinin A-induced bronchoconstriction in asthmatics. J. Van Schoor, G.F. Joos, B.L. Chasson, R.J. Brouard, R.A. Pauwels. OERS Journals Ltd 1998.

ABSTRACT: Inhalation of neurokinin (NK) A causes bronchoconstriction in patients with asthma. The NKA-induced bronchoconstriction in isolated human airways is mediated via the NK2 receptor and inhibited by SR 48968, a potent and specific nonpeptide tachykinin NK2 receptor antagonist. In the present study, the effect of orally administered SR 48968 on NKA-induced bronchoconstriction was examined in 12 mild asthmatics.

On the screening day and during the study periods, increasing concentrations of NKA $\left(3.3 \times 10^{-9}\right.$ to $\left.1.0 \times 10^{-6} \mathrm{~mol} \cdot \mathrm{mL}^{-1}\right)$ were inhaled, until the forced expiratory volume in one second (FEV1) and specific airway conductance ( $(\mathrm{G}$ aw) decreased by at least 20 and $50 \%$, respectively. During the study periods, $100 \mathrm{mg}$ SR 48968 or matched placebo was ingested in a double-blind, randomized, crossover fashion and NKA provocation was performed at 1.5 and $24 \mathrm{~h}$ after dosing.

At $1.5 \mathrm{~h}$, the mean (SEM) $\log 10$ provocative concentration of NKA causing a $20 \%$ fall in FEV1 (PC20 FEV1) was -6.25 (0.20) after SR 48968 and -6.75 (0.17) after placebo $(p=0.05)$; the mean $\log 10$ provocative concentration of NKA causing a $35 \%$ fall in $\mathrm{s} G$ aw $\left(\mathrm{PC} 35 \mathrm{~s} G_{\text {aw }}\right)$ was $-7.02(0.28)$ after $S R 48968$ and $-7.64(0.19)$ after placebo (p=0.05). At $24 \mathrm{~h}$, the mean log10 PC20 FEV1 was -6.21 (0.17) after SR 48968 and -6.65 (0.11) after placebo $(p=0.05)$; the mean $\log 10$ PC35 $s G$ aw was $-6.85(0.23)$ after SR 48968 and -7.17 (0.15) after placebo (nonsignificant). As PC20 FEV1 and/or PC35 sG aw were not reached in up to 4 patients per SR 48968 group, the differences between SR 48968 and placebo were underestimated.

In conclusion, oral treatment with $100 \mathrm{mg}$ SR 48968 caused a significant inhibition of neurokinin A-induced bronchoconstriction in asthmatics. This finding constitutes the first evidence of inhibition of sensory neuropeptide-induced bronchoconstriction by a selective tachykinin receptor antagonist in humans. Eur Respir J 1998; 12: 17-23.
\end{abstract}

*Dept of Respiratory Diseases, University Hospital, Ghent, Belgium. ${ }^{+}$Sanofi Recherche, Montpellier, France.

Correspondence: J. Van Schoor

Dept of Respiratory Diseases

University Hospital

De Pintelaan 185

B-9000 Ghent

Belgium

Fax: 3292402341

Keywords: Asthma

bronchoconstriction

neurokinin A

tachykinin receptor antagonists

tachykinins

Received: October 241997

Accepted after revision April 121998
Substance P (SP) and neurokinin (NK) A are members of the tachykinin peptide family and have been implicated as neurotransmitters which mediate the excitatory part of the nonadrenergic, noncholinergic (e-NANC) nervous system [1-3]. In the human airways, they are contained within sensory unmyelinated $\mathrm{C}$ nerve fibres, which are distributed beneath or within the airway epithelium, around blood vessels and glands, within the bronchial smooth muscle layer and around local ganglion cells [4-8]. Recent findings in both experimental animals and humans, however, suggest that non-neural cells (endothelial cells, eosinophils and macrophages), either resident or circulating, can also be a source of tachykinins and that immune stimuli can boost tachykinin production from immunocytes [9]. A reduced SP-like immunoreactivity (SP-LI) content of asthmatic airways compared with nonasthmatic subjects has been reported, suggesting an augmented SP release in asthma [10]. Supporting this hypothesis, bronchoalveolar lavage fluid [11] and induced sputum [12] from asthmatics were found to contain increased amounts of
SP-LI. SP and NKA contract human airways in vitro and in vivo, NKA being more potent than SP and asthmatics being more sensitive than normal subjects [5, 13-17]. Other potentially important airway effects of tachykinins include mucus secretion, cough, vasodilatation, increased vascular permeability and a broad array of pro-inflammatory effects involving various types of leukocytes [1-3].

SP and NKA interact with their target cells in the airways through specific tachykinin receptors, with SP being the preferential agonist for the tachykinin NK1 receptor and NKA the preferential agonist for the tachykinin NK2 receptor [18]. Increased expression of NK1 [19] and NK2 [20] tachykinin receptor gene messenger ribonucleic acid (mRNA) in asthmatic airways has been reported. In isolated normal human airways in vitro, tachykinin-induced bronchoconstriction is mediated predominantly by tachykinin NK2 receptors [8, 21-23]; recently, however, involvement of tachykinin NK1 receptors has also been noted $[24,25]$. Tachykinin NK1 receptor stimulation appears to be important in eliciting neurogenic inflammation $[1-3,18]$. 
Because of their presence and release in the airways and their ability to mimic various pathophysiological features of asthma, SP and NKA fulfil two of the three criteria for a presumed mediator of asthma; their pathogenetic role will be defined through the use of tachykinin antagonists in clinical trials of asthmatics.

SR 48968 (saredutant) is a potent ( $p \mathrm{~A}_{2}=9.40$ on isolated human bronchus) and selective competitive nonpeptide tachykinin NK2 receptor antagonist $[22,23,26]$. In order to clarify further the in vivo mechanisms underlying the NKA-induced bronchoconstriction in patients with asthma, the effect of SR 48968 in asthmatics was studied in a double-blind, randomized and placebo-controlled trial.

\section{Subjects and methods}

\section{Patients}

Twelve male, adult, nonsmoking subjects with stable mild-to-moderate asthma were recruited for the trial. All participants met the American Thoracic Society diagnostic criteria for asthma [27] and no relevant concomitant diseases were present. All patients were atopic.

The only treatment allowed during the study period consisted of inhaled salbutamol. Patients number 1 and 7 were receiving inhaled glucocorticosteroids (budesonide $800 \mu \mathrm{g} \cdot \mathrm{day}^{-1}$ and $400 \mu \mathrm{g} \cdot \mathrm{day}^{-1}$, respectively) and discontinued its use at least 2 weeks before the first screening visit. Their morning baseline forced expiratory volume in one second (FEV1) was Š70\% of predicted and the provocative concentration causing a $20 \%$ fall in FEV1 (PC20 FEV1) methacholine was $<8 \mathrm{mg} \cdot \mathrm{mL}^{-1}$. No patients were studied within 4 weeks of an upper respiratory tract infection or exacerbation of asthma.

The study protocol was approved by the ethical committee of the University Hospital of Ghent. All participants gave their written informed consent.

\section{Study design}

This study was of a randomized, double-blind, placebocontrolled, two-period, crossover design. On the screening day, the patients underwent an NKA inhalation challenge. To be eligible for inclusion in the trial, they had to experience a fall in FEV1 of at least 10\%, compared with their prechallenge value. All screened patients fulfilled this criterion. The screening tests had to be performed within the week prior to the start of the study (study period 1). Both study periods comprised about $25 \mathrm{~h}$, during which the participants were hospitalized in the clinical unit of the Department of Respiratory Diseases, including an overnight stay. The patients arrived at the department at around 08:00 h, following an overnight fast of at least $8 \mathrm{~h}$.

The study medication, $100 \mathrm{mg}$ of SR 48968 ((s)- $N$ methyl- $N$-(4-acetylamino-4-phenylpiperidino)-2-(3,4-dichlorophenyl) butylbenzamide succinate) or matched placebo (formulated as four capsules), was ingested with $100 \mathrm{~mL}$ of tap water. An NKA challenge was performed at 1.5 and $24 \mathrm{~h}$ post-dose. The baseline FEV1 before each NKA challenge had to be within $15 \%$ of the baseline FEV1, obtained at the screening visit; if this was not the case, the patient was rescheduled for another visit. Foods and beverages containing caffeine had to be discontinued for at least $24 \mathrm{~h}$ before each study period and until the end of each period. Short-acting inhaled $\beta_{2}$-agonists were withheld for at least $10 \mathrm{~h}$ before each NKA challenge. Breakfast was served $3 \mathrm{~h}$ post-dose, after completing the NKA challenge, while lunch and dinner were served 6 and $12 \mathrm{~h}$ post-dose, respectively. The next morning, breakfast was served after completion of the NKA challenge ( $24 \mathrm{~h}$ postdose), following which the patients were allowed to leave the clinic. They returned $48 \mathrm{~h}$ post-dose for a safety control visit (enquiry into adverse events, changes in concomitant medication and blood sampling).

Study period 2 was performed after a wash-out of 3-6 days after the first trial drug ingestion. Patients were requested to avoid all strenuous physical efforts from the week preceding study period 1 until the end of the study.

\section{Pulmonary function testing}

The specific airway conductance ( $\mathrm{s} G \mathrm{aw}$ ) was measured with a constant volume body plethysmograph (Jaeger, Würzburg, Germany). sGaw was calculated from airway resistance and thoracic gas volume, using the MasterLab software package (version 3.2, 1991, Jaeger), installed on a personal computer. Each value represents the mean of five consecutive manoeuvres. The FEV1 was obtained from flow-volume loops, obtained from a pneumotachograph, using the same apparatus and software. The highest value of three consecutive manoeuvres was accepted for evaluation at each performance. sGaw was always measured before the FEV1, to avoid changes in airway calibre in response to deep inhalation. All manoeuvres were performed with the patient in the sitting position, the nose occluded by a clip. The same lung function technician and body box were used throughout the study.

\section{Bronchial challenge tests}

The PC20 for methacholine was determined by measuring the decrease in FEV1 after inhalation of doubling concentrations of methacholine, according to the method of COCKCROFT et al. [28].

NKA was inhaled using a protocol slightly modified from our previous work [15]. Before each NKA inhalation challenge, baseline $s G$ aw and FEV1 were determined. The patients then inhaled the NKA diluent and $s G$ aw and $F E V 1$ were measured 3 and $7 \mathrm{~min}$ after the start of the inhalation, with the lowest value of each being considered as the postdiluent baseline $s G$ aw and FEV1, respectively. The actual NKA challenge was performed provided the FEV1 did not fall by $>10 \%$ after inhaling diluent. During the challenge, increasing concentrations of NKA $\left(3.3 \times 10^{-9}\right.$, $1.0 \times 10^{-8}, 3.3 \times 10^{-8}, 1.0 \times 10^{-7}, 3.3 \times 10^{-7}$ and $\left.1.0 \times 10^{-6} \mathrm{~mol} \cdot \mathrm{mL}^{-1}\right)$ were inhaled until FEV1 fell by at least $20 \%$ and $\mathrm{s} G$ aw decreased by at least $50 \%$ of the respective postdiluent baseline values.

NKA was obtained from Peninsula (St Helens, UK) and was diluted in saline containing $1 \%$ human serum albumin (Behringwerke, Marburg, Germany). The dilutions of NKA were freshly prepared on the morning of the challenge and kept on ice until nebulization. The aerosols were produced 
using a Mallinckrodt jet nebulizer (Mallinckrodt Diagnostica, Petten, The Netherlands); this method has been validated and described previously [17, 29]. First, a collapsible $30 \mathrm{~L}$ plastic bag, which served as a drying chamber, was filled with nitrogen $\left(\mathrm{N}_{2}\right)$ gas. Then, $0.5 \mathrm{~mL}$ of diluent or each subsequent NKA concentration was sprayed by compressed $\mathrm{N}_{2}(400 \mathrm{kPa})$ in $60 \pm 10 \mathrm{~s}$ into the drying chamber, in which the droplets evaporated rapidly to dry particles. Finally, the patient inhaled the aerosol from the bag in 2 min by quiet tidal breathing through a three-way valve and a mouthpiece, until the collapse of the bag. Supplementary oxygen (at a flow rate of $4 \mathrm{~L} \cdot \mathrm{min}^{-1}$, inspiratory oxygen fraction $\left.\left(F \mathrm{I}, \mathrm{O}_{2}\right)=0.995\right)$ was supplied into the mouthpiece. The patient performed the inhalation in the sitting position, with the nose occluded by a clip. Pulmonary function measurements ( $\mathrm{s} G$ aw and $\mathrm{FEV} 1$ ) were performed at 3 and $7 \mathrm{~min}$ after the start of the inhalation of each concentration. The nebulizations of the different concentrations were initiated at $10 \mathrm{~min}$ intervals. The NKA challenge was stopped when PC20 FEV1 NKA and PC35 sGaw NKA could be calculated. A PC20 or PC 35 value of $3.3 \times 10^{-6} \mathrm{~mol} \cdot \mathrm{mL}^{-1}$ (a $0.5 \log$ higher concentration than the highest concentration tested) was attributed arbitrarily in those cases where the desired fall in FEV1 or sGaw was not obtained.

\section{Plasma for SR 48968 levels}

Blood samples for the quantification of SR 48968 plasma concentrations were taken predose and at $1.5 \mathrm{~h}, 3 \mathrm{~h}$ (before breakfast) and $24 \mathrm{~h}$ post-dose in each study period. Samples $(6 \mathrm{~mL})$ were collected into polypropylene sodium heparin tubes and immediately after sampling, the tubes were centrifuged at $1500 \times \mathrm{g}$ for $10 \mathrm{~min}$. The plasma was then pipetted into polypropylene tubes and stored at $-20^{\circ} \mathrm{C}$, until batch analysis. Quantification of SR 48968 was performed using gas chromatography with electron capture detection. This method has a limit of detection of 0.5 $\mathrm{ng} \cdot \mathrm{mL}^{-1}$ and a limit of quantification of $1.0 \mathrm{ng} \cdot \mathrm{mL}^{-1}$ (data on file at Sanofi).

\section{Statistical analysis}

Comparisons of the predose baseline FEV1 values between the SR 48968 group and the placebo group, and of the postdiluent baseline FEV1 values in these two groups were performed using a Wilcoxon matched-pairs test.

The values of PC20 FEV1 NKA and PC35 sGaw NKA (expressed in $\mathrm{mol} \cdot \mathrm{mL}^{-1}$ ) were $\log 10$ transformed; treatment with SR 48968 was compared with placebo, at $1.5 \mathrm{~h}$ and $24 \mathrm{~h}$ post-dose, by means of a cross-over analysis of variance (ANOVA) test. A p-value ð0.05 was considered significant. Data are expressed as the mean \pm sem of the logarithmically transformed values. The relationship between the level of protection and the serum SR 48968 concentration, at $1.5 \mathrm{~h}$ and at $24 \mathrm{~h}$ post-dose, was calculated using Spearman's rank correlation test. The level of protection at a given time point was defined as the difference between the $\log 10$ PC20 FEV1 NKA value on the SR 48968 day and that on the placebo day for individual patients.

\section{Results}

\section{Patients}

Twelve patients, aged 19-36 yrs (mean 28.6 yrs), participated in the trial. Their mean ( \pm SEM) baseline FEV 1 was $4.20 \pm 0.20 \mathrm{~L}$ or $96.6 \pm 4.4 \%$ of predicted. Their mean PC20 FEV1 methacholine was $5.2 \pm 0.6 \mathrm{mg} \cdot \mathrm{mL}^{-1}$ (table 1 ).

\section{Effects of SR 48968 on baseline FEVI}

There were no statistically significant differences between the predose baseline mean ( \pm SEM) FEV 1 values on the SR $48968(4.04 \pm 0.18 \mathrm{~L})$ and the placebo day $(4.03 \pm 0.17$ L) $(\mathrm{p}=1.000)$, or between the postdiluent baseline mean $( \pm$ SEM) FEV1 values on these two days $(3.98 \pm 0.18 \mathrm{~L}$ for SR 48968 versus $3.94 \pm 0.17 \mathrm{~L}$ for placebo) $(\mathrm{p}=0.656)$.

\section{Reproducibility of the neurokinin A challenge}

At screening, all 12 subjects responded to NKA inhalation and the mean $\log 10$ PC20 FEV1 NKA was $-6.93 \pm 0.15$. After placebo, the mean $\log 10$ PC20 FEV1 NKA was $-6.75 \pm 0.17$ and $-6.65 \pm 0.11$ at $1.5 \mathrm{~h}$ and $24 \mathrm{~h}$ post-dose, respectively. The mean "maximal" percentage fall in FEV1 after inhalation of NKA at which a fall in FEV 1 of Š $20 \%$ was reached, was $-26.6 \pm 1.3$ at screening, $-27.0 \pm 2.6$ at $1.5 \mathrm{~h}$ post-dose and $-30.5 \pm 2.6$ at $24 \mathrm{~h}$ post-dose on the placebo day.

\section{Effect of SR 48968 on neurokinin A-induced bronchocon-} striction

At $1.5 \mathrm{~h}$ post-dose, the mean $\log 10 \mathrm{PC} 20 \mathrm{FEV} 1 \mathrm{NKA}$ was $-6.25 \pm 0.20$ after SR 48968 and $-6.75 \pm 0.17$ after placebo ( $\mathrm{p}=0.05$ ) (fig. 1). The cumulative dose-response curves of the individual patients are shown in figure 2 . Inhalation of NKA caused a dose-dependent bronchoconstriction on both study days; there was a consistent rightward shift in the cumulative dose-response curves after administration

Table 1. - Patient characteristics

\begin{tabular}{lcccc}
\hline $\begin{array}{l}\text { Subject } \\
\text { No. }\end{array}$ & $\begin{array}{c}\text { Age } \\
\text { yrs }\end{array}$ & $\begin{array}{c}\text { Baseline } \\
\text { FEV1 } \\
\text { L }\end{array}$ & $\begin{array}{c}\text { Baseline } \\
\text { FEV1 } \\
\text { \% pred }\end{array}$ & $\begin{array}{c}\text { PC20 } \\
\text { methacholine } \\
\text { mg·mL-1 }\end{array}$ \\
\hline $1 *$ & 32 & 4.76 & 110 & 5.7 \\
2 & 34 & 3.72 & 88 & 5.3 \\
3 & 35 & 4.84 & 119 & 6.9 \\
4 & 22 & 4.04 & 90 & 6.5 \\
5 & 36 & 3.24 & 73 & 2.2 \\
6 & 26 & 5.04 & 119 & 7.0 \\
$7 *$ & 30 & 3.16 & 76 & 3.3 \\
8 & 32 & 3.88 & 86 & 8.0 \\
9 & 33 & 3.68 & 91 & 6.1 \\
10 & 19 & 5.28 & 105 & 5.5 \\
11 & 21 & 4.20 & 92 & 2.6 \\
12 & 24 & 4.52 & 92 & 3.0 \\
\hline
\end{tabular}

*: patient stopped inhaled glucocorticosteroid treatment 2 weeks before entering the trial. FEV1: forced expiratory volume in one second; PC20: provocative concentration causing a $20 \%$ fall in FEV1. 
of SR 48968, with the exception of one case (patient number 1). A protective effect of SR 48968 was noted in the other 11 patients, but a fall of $20 \%$ was not reached in three of them. In one of these (patient number 4), PC20 was not reached on either study day. From this patients individual dose-response curve (fig. 2), however, it can be seen that FEV1 remained unchanged after SR 48968, while it decreased by $10.6 \%$ after placebo.

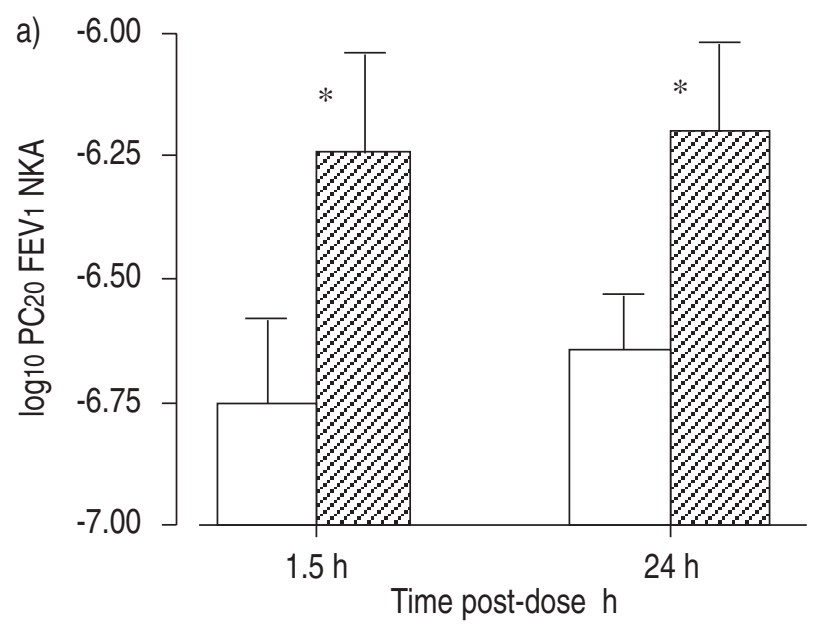

The mean $\log 10$ PC35 sGaw NKA was $-7.02 \pm 0.28$ after SR 48968 and $-7.64 \pm 0.19$ after placebo $(p=0.05)$ (fig. 1). A protective effect of SR 48968 was noted in 10 out of 12 patients and $\mathrm{PC} 35$ was not reached in one of them.

At $24 \mathrm{~h}$ post-dose, the mean $\log _{10} \mathrm{PC}_{20} \mathrm{FEV} 1 \mathrm{NKA}$ was $-6.21 \pm 0.17$ after SR 48968 and $-6.65 \pm 0.11$ after placebo ( $p=0.05$ ) (fig. 1). A protective effect of SR 48968 was observed in eight out of 12 patients and $\mathrm{PC}_{20}$ was not

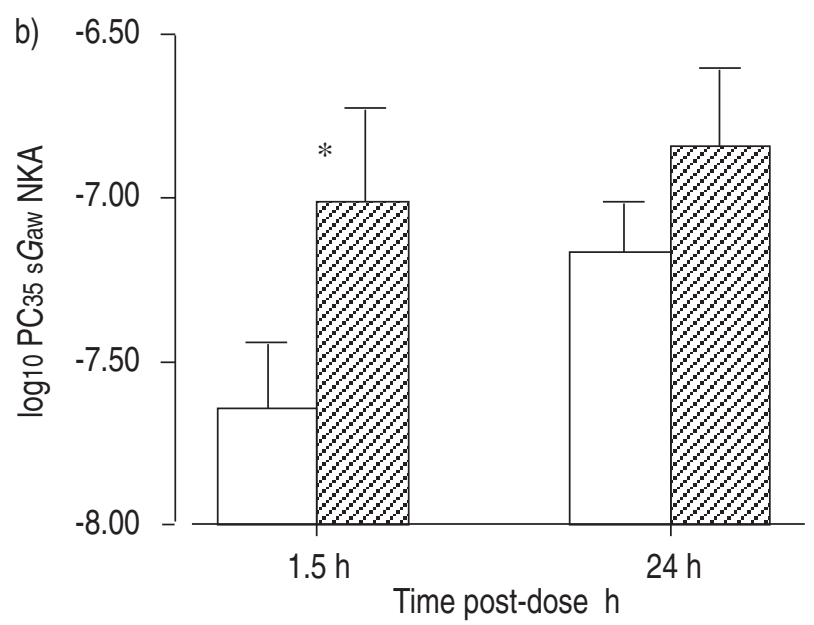

Fig. 1. - Bar graphs representing the mean (SEM) values of a) $\log 10$ of the provocative concentration of neurokinin (NK) A causing a $20 \%$ fall in the forced expiratory volume in one second ( $\mathrm{PC}_{20} \mathrm{FEV} 1 \mathrm{NKA}$ ) and b) $\log 10$ of the provocative concentration of NKA causing a 35\% fall in specific airway conductance (PC35 sGaw NKA) at $1.5 \mathrm{~h}$ and at $24 \mathrm{~h}$ post-dose, respectively. $Z$ : SR 48968; $\square:$ placebo. *: pð0.05, statistically significant differences.
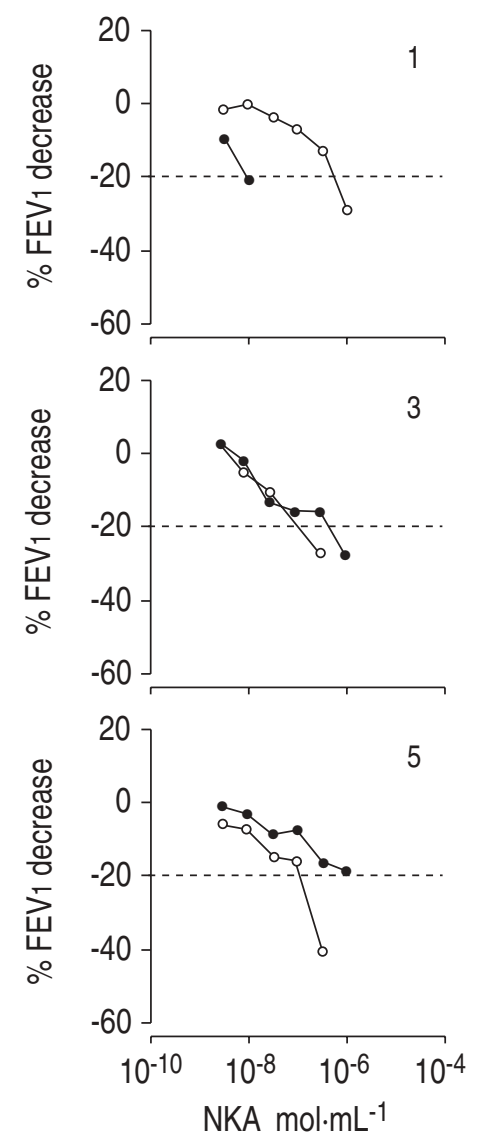

Fig. 2. - Cumulative dose-response curves of individual patients at $1.5 \mathrm{~h}$ post-dose. Changes in the forced expiratory volume in one second (FEV1) in response to neurokinin A (NKA) inhalation are expressed as the percentage change from the postdiluent baseline FEV1 value. $\bullet:$ SR 48968 ; $\bigcirc:$ placebo. Numbers indicate subject numbers.
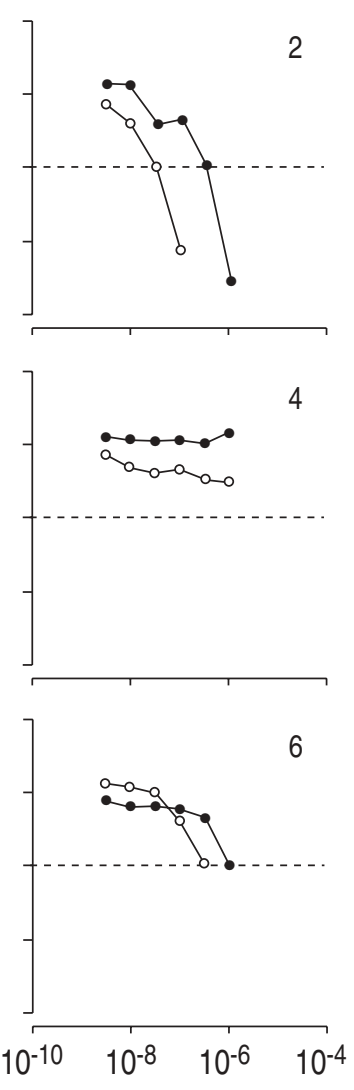

NKA $\mathrm{mol} \cdot \mathrm{mL}^{-1}$
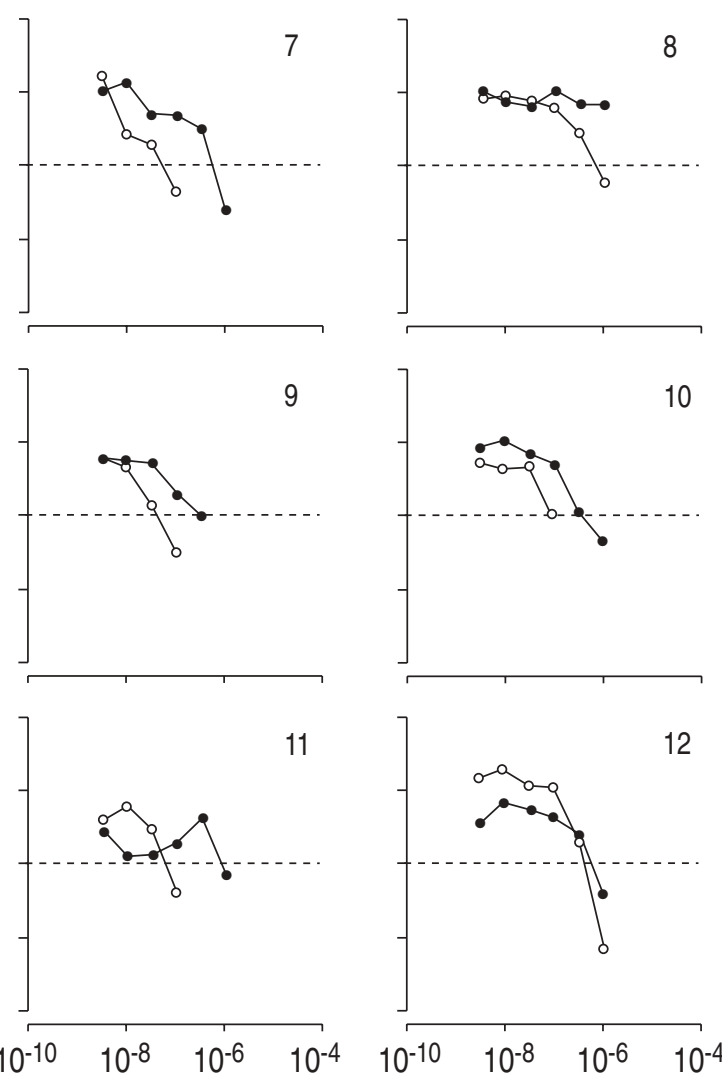

12

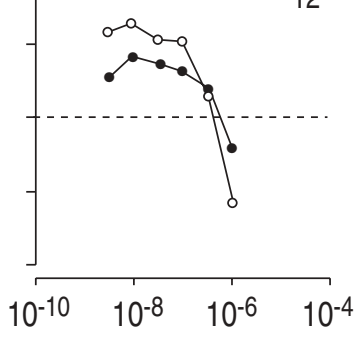

$\mathrm{NKA} \mathrm{mol} \cdot \mathrm{mL}^{-1}$ 
reached in four of them. The mean $\log 10$ PC35 sGaw NKA was $-6.85 \pm 0.23$ after SR 48968 and $-7.17 \pm 0.15$ after placebo (not significant) (fig. 1). A protective effect of SR 48968 was seen in seven out of 12 patients and PC35 was not reached in two of them.

\section{Plasma concentrations of SR 48968}

The mean (range) SR 48968 plasma levels at $1.5 \mathrm{~h}, 3 \mathrm{~h}$ and $24 \mathrm{~h}$ post-dose were $38.2(14.5-92.6) \mathrm{nmol} \cdot \mathrm{L}^{-1}, 44.2$ $(8.0-171.7) \mathrm{nmol} \cdot \mathrm{L}^{-1}$, and $2.8(0.0-16.3) \mathrm{nmol} \cdot \mathrm{L}^{-1}$, respectively. There was no significant correlation between the protective effect and the plasma SR 48968 levels at $1.5 \mathrm{~h}$ post-dose, at $24 \mathrm{~h}$ post-dose and after pooling of both groups (Spearman's test: $0.462,-0.404$ and 0.170 , respectively) (table 2 and fig. 3).

Table 2. - Protective effect* and plasma SR 48968 levels at $1.5 \mathrm{~h}$ and $24 \mathrm{~h}$ post-dose

\begin{tabular}{ccccc}
\hline & \multicolumn{2}{c}{$1.5 \mathrm{~h}$} & \multicolumn{2}{c}{$24 \mathrm{~h}$} \\
\cline { 2 - 4 } $\begin{array}{l}\text { Subject } \\
\text { No. }\end{array}$ & Protection & $\begin{array}{c}\text { SR 48968 } \\
\text { nmol·L-1 }\end{array}$ & Protection & $\begin{array}{c}\text { SR 48968 } \\
\text { nmol·L }\end{array}$ \\
\hline 1 & -1.75 & 16.123 & $1.23^{\dagger}$ & 0.000 \\
2 & 1.02 & 38.768 & 0.40 & 3.261 \\
3 & 0.52 & 33.333 & -0.06 & 0.000 \\
4 & $0.00^{\dagger}$ & 92.572 & $0.69 \dagger$ & 16.304 \\
5 & $1.45^{\dagger}$ & 47.101 & -0.23 & 1.993 \\
6 & 0.48 & 14.493 & $0.93 \dagger$ & 0.000 \\
7 & 1.00 & 25.543 & 0.75 & 0.000 \\
8 & $0.69 \dagger$ & 44.203 & -0.22 & 2.536 \\
9 & 0.85 & 42.754 & 0.73 & 3.804 \\
10 & 0.60 & 19.022 & 0.05 & 2.355 \\
11 & 1.10 & 61.594 & -0.07 & 3.261 \\
12 & 0.14 & 23.370 & $1.10^{\dagger}$ & 0.000 \\
\hline
\end{tabular}

*: the protective effect is defined as the difference between the $\log 10$ of the provocative concentration of neurokinin A (NKA) causing a $20 \%$ fall in the forced expiratory volume in one second (PC20 FEV1 NKA) value on the SR 48968 day and that on the placebo day. $\div$ : a $20 \%$ fall in FEV1 was not reached; a $\mathrm{PC}_{20}$ FEV1 NKA value of $3.3 \times 10^{-6} \mathrm{~mol} \cdot \mathrm{mL}^{-1}$ was attributed arbitrarily, thus potentially underestimating the magnitude of the protection.

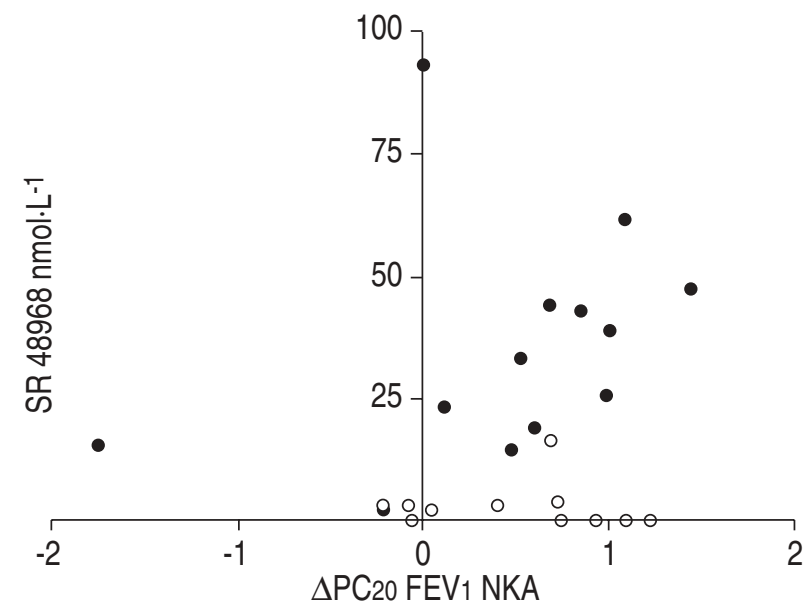

Fig. 3. - Scatterplot of the relationship between the protective effect, expressed as the change in the provocative concentration of neurokinin (NK) A causing a $20 \%$ fall in the forced expiratory volume in one second (PC20 FEV1 NKA) and the SR 48968 plasma levels. $\bullet: 1.5$ h postdose; $\bigcirc$ : 24 h post-dose (see also table 2)
Drug safety

SR 48968 was biologically and clinically well tolerated and no serious adverse events were noted. Two non serious adverse events were noted: patients number 7 and 11 both experienced mild frontal headache on the active treatment day; in both cases it subsided spontaneously until complete recovery.

\section{Discussion}

In this study, it was demonstrated that the tachykinin NK2 receptor antagonist SR 48968 inhibits NKA-induced bronchoconstriction in patients with asthma. A protective effect was observed both at $1.5 \mathrm{~h}$ and $24 \mathrm{~h}$ post-dose. The shift in the concentration-response curve, however, was modest and less pronounced than would have been predicted from previous in vitro experiments [22]. The calculated mean level of protection against the NKA-induced fall in FEV1 was $0.5 \log 10$ units at $1.5 \mathrm{~h}$ post-dose. However, there were marked interindividual differences in the protection conveyed by SR 48968: complete protection was observed in three patients, whilst a varying degree of partial protection was present in the remaining patients. A PC20 value of $0.5 \log$ higher than the highest concentration was arbitrarily introduced in the three patients who did not develop a $20 \%$ fall in FEV1 after active treatment. The calculated mean protection is thus very likely to be underestimated. A small protective effect of SR 48968 was still observed $24 \mathrm{~h}$ post-dose. Again, the protective effect of SR 48968 was probably underestimated, as an extrapolation of $\mathrm{PC}_{20} \mathrm{FEV}_{1}$ NKA was necessary in four subjects.

The results of this study show that at least part of the NKA-induced bronchoconstriction in asthma is mediated via activation of the tachykinin NK2 receptor. Pharmacokinetic factors such as dose, absorption and penetration may contribute to the apparently limited protection. Poor absorption of SR 48968 from the gastrointestinal tract or poor penetration of SR 48968 from the circulation into the airway mucosa, however, may be excluded. Indeed, the mean plasma level of SR 48968 reached at the moment of the first NKA challenge ( $1.5 \mathrm{~h}$ post-dose) was $38 \mathrm{nmol} \cdot \mathrm{L}^{-1}$. In the presence of $30 \mathrm{nmol} \cdot \mathrm{L}^{-1} \mathrm{SR} 48968$ in an in vitro experiment on isolated human airways [22], the rightward shift in the concentration-response curve of [Nle $\left.{ }^{10}\right]-\mathrm{NKA}$ (4-10), a specific tachykinin NK2 receptor agonist, approximated the observed shift in the concentration-response curve for NKA in the present patients. Thus, the serum levels reached in these patients have been shown to be effective in vitro. The data therefore strongly suggest that the dose of SR 48968 chosen for this clinical study was adequate. Furthermore, animal data have shown that SR 48968 readily penetrates the airways in vivo $[26,30]$. In the guinea-pig or the BDE rat in vivo, SR 48968 administered intraduodenally $\left(500 \mu \mathrm{g} \cdot \mathrm{kg}^{-1}\right)$ [26] or intravenously $\left(1 \mathrm{mg} \cdot \mathrm{kg}^{-1}\right)$ [30] almost completely abolished the bronchoconstriction caused by NKA or its synthetic analogues.

The finding of residual protection at $24 \mathrm{~h}$ post-dose, at a time when virtually all of the circulating active drug had disappeared, suggests a local accumulation of SR 48968 in the airways, the presence of active metabolites of SR 
48968 or a long-lasting inhibition of the bronchial tachykinin NK2 receptor. As far as we are aware, no data addressing these issues in humans have been published to date. Following oral administration of $1 \mathrm{mg} \cdot \mathrm{kg}^{-1} \mathrm{SR} 48968$ to guinea-pigs in vivo, there was still demonstrable protection against [Nle $\left.{ }^{10}\right]-\mathrm{NKA}(4-10)$-induced bronchoconstriction at $24 \mathrm{~h}$ post-dose; the protection offered was less marked than that found at $2.5 \mathrm{~h}$ post-dose [31].

It could be argued that SR 48968 had a nonspecific protective effect. A control bronchoprovocation with a chemically unrelated bronchoconstrictor, such as methacholine, was not included in the study, given the convincing data in vitro on isolated human bronchi and in vivo in several experimental animal species. Indeed, SR 48968 was shown to be a specific and potent tachykinin NK2 receptor antagonist, as it does not modify concentration-response curves to acetylcholine, histamine, $\mathrm{KCl}$, prostaglandin $\mathrm{F}_{2 \alpha}\left(\mathrm{PGF}_{2 \alpha}\right)$ or specific tachykinin NK1 receptor agonists in vitro in human bronchi $[22,25]$. In addition, the specificity of SR 48968 for the NK2 receptor has also been confirmed in vivo in several animal species, such as rats and guineapigs $[26,30,32]$.

An important explanation for the modest protective effect of SR 48968 may lie in the fact that NKA is not a specific, but only a preferential tachykinin NK2 receptor agonist; NKA also activates the tachykinin NK1 receptor. Results from pharmacological studies on isolated bronchi from guinea-pigs [33] and humans [25] suggest that the NKA-induced bronchoconstriction is not only due to an NK2 receptor-mediated stimulation of airway smooth muscle, but also to an indirect tachykinin NK1 receptor-mediated activation of airway inflammatory cells such as mast cells, with the release of secondary mediators $[34,35]$. In guinea-pig isolated bronchi, the noncholinergic bronchoconstriction produced by electrical field stimulation was shown to be largely mediated by endogenously released tachykinins; pretreatment with specific tachykinin receptor antagonists demonstrated that both tachykinin NK1 and NK2 receptors mediate this contraction [33]. Recently, evidence was provided for the presence of functional tachykinin NK1 receptors in human airways, in addition to tachykinin NK2 receptors. Indeed, NALINE et al. [25] reported that stimulation by SP and specific tachykinin NK1 receptor agonists induced a prostanoid-dependent indirect contraction in isolated small human airways. Moreover, upregulation of tachykinin NK1 [19] as well as NK2 [20] receptors has been reported in asthmatic airways.

It is therefore hypothesized that the NKA-induced bronchoconstriction in asthmatics occurs through a combination of direct, tachykinin NK2 receptor-mediated smooth muscle contraction (antagonized by specific tachykinin NK2 receptor antagonists such as SR 48968) and an indirect mechanism involving tachykinin NK1 receptor stimulation (unaffected by SR 48968). The relative importance of NK1 and NK2-mediated bronchoconstrictor responses in asthmatics has not yet been studied.

In conclusion, in this study it was demonstrated that the potent and specific nonpeptide tachykinin NK2 receptor antagonist SR 48968 (saredutant) offers a small (probably underestimated) but significant level of protection against inhaled NKA-induced bronchoconstriction in mild asthmatics. This finding constitutes the first evidence of such inhibition by a tachykinin NK2 receptor antagonist in humans. Studies using tachykinin receptor antagonists in other settings have been published previously. These involved the low-potency mixed NK1/NK2 receptor antagonist FK-224 and the NK1 antagonists FK-888 and CP-99994. Bradykinin-induced bronchoconstriction in asthmatics was attenuated by $4 \mathrm{mg}$ [36], but not $2 \mathrm{mg}$ [37], of inhaled FK224. Although this suggested that tachykinin release from airway sensory nerves is involved in responses to bradykinin, this hypothesis could not be confirmed in another study by our group, as no protective effect could be demonstrated of $4 \mathrm{mg}$ of inhaled FK-224 against NKAinduced bronchoconstriction in asthmatics [38]. Inhaled FK-888 was shown to shorten the recovery phase of exercise-induced airway narrowing to some extent, albeit without influencing the maximal fall in sGaw [39]. Finally, intravenously administered CP-99994 did not significantly inhibit hypertonic saline-induced bronchoconstriction or cough in mild asthmatics [40].

Further clinical studies with potent and specific nonpeptide tachykinin receptor antagonists, including neurokinin- 1 and combined neurokinin-1/2 antagonists, are clearly needed to explore the therapeutic potential of tachykinin antagonism in asthma [41].

\footnotetext{
Acknowledgements: The authors wish to thank V. Collart for the lung function measurements, A. Neessens, I. De Borle and M.-R. Mouton for the preparation of the neurokinin A solutions, C. Vandeven for help in preparing the manuscript, and M. Kindermann for the statistical analysis. The authors also greatly acknowledge the cooperation of Z. Diamant and P. Sterk (Dept of Respiratory Diseases, University of Leiden, The Netherlands), in sharing their experience with the neurokinin A nebulization technique methodology.
}

\section{References}

1. Lundberg JM, Saria A. Polypeptide-containing neurons in airway smooth muscle. Annu Rev Physiol 1987; 49: 557-572.

2. Barnes PJ, Baraniuk JN, Belvisi MG. Neuropeptides in the respiratory tract. Part I. Am Rev Respir Dis 1991; 144: 1187-1198.

3. Barnes PJ, Baraniuk JN, Belvisi MG. Neuropeptides in the respiratory tract. Part II. Am Rev Respir Dis 1991; 144: 1391-1399.

4. Lundberg JM, Hökfelt T, Martling CR, Saria A, Cuello C. Substance P-immunoreactive sensory nerves in the lower respiratory tract of various mammals including man. Cell Tissue Res 1984; 235: 251-261.

5. Martling CR, Theodorsson-Norheim E, Lundberg JM. Occurrence and effects of multiple tachykinins; substance $\mathrm{P}$, neurokinin $\mathrm{A}$ and neuropeptide $\mathrm{K}$ in human lower airways. Life Sci 1987; 40: 1633-1643.

6. Komatsu T, Yamamoto M, Shimokata K, Nagura H. Distribution of substance P-immunoreactive and calcitonin gene-related peptide-immunoreactive nerves in normal human lungs. Int Arch Allergy Appl Immunol 1991; 95: 23-28.

7. Luts A, Uddman R, Alm P, Basterra J, Sundler F. Peptidecontaining nerve fibers in human airways: distribution and coexistence pattern. Int Arch Allergy Immunol 1993; 101: 52-60.

8. Sheldrick RLG, Rabe KF, Fischer A, Magnussen H, Coleman RA. Further evidence that tachykinin-induced contraction of human isolated bronchus is mediated only by NK2-receptors. Neuropeptides 1995; 29: 281-292. 
9. Maggi CA. The effects of tachykinins on inflammatory and immune cells. Regul Peptides 1997; 70: 75-90.

10. Lilly CM, Bai TR, Shore SA, Hall AE, Drazen JM. Neuropeptide content of lungs from asthmatic and nonasthmatic patients. Am J Respir Crit Care Med 1995; 151: 548553.

11. Nieber K, Baumgarten CR, Rathsack R, Furkert J, Oehme $P$, Kunkel G. Substance P and $\beta$-endorphin-like immunoreactivity in lavage fluids of subjects with and without allergic asthma. J Allergy Clin Immunol 1992; 90: 646652.

12. Tomaki M, Ichinose M, Miura M, et al. Elevated substance $\mathrm{P}$ content in induced sputum from patients with asthma and patients with chronic bronchitis. Am J Respir Crit Care Med 1995; 151: 613-617.

13. Advenier C, Naline E, Drapeau G, Regoli D. Relative potencies of neurokinins in guinea pig trachea and human bronchus. Eur J Pharmacol 1987; 139: 133-137.

14. Frossard N, Barnes PJ. Effect of tachykinins in small human airways. Neuropeptides 1991; 19: 157-161.

15. Joos G Pauwels R, Van Der Straeten M. Effect of inhaled substance $\mathrm{P}$ and neurokinin $\mathrm{A}$ on the airways of normal and asthmatic subjects. Thorax 1987; 42: 779-783.

16. Crimi N, Palermo F, Oliveri R, et al. Effect of nedocromil on bronchospasm induced by inhalation of substance $\mathrm{P}$ in asthmatic subjects. Clin Allergy 1988; 18: 375-382.

17. Cheung D, Bel EH, Den Hartigh J, Dijkman JH, Sterk PJ. The effect of an inhaled neutral endopeptidase inhibitor, thiorphan, on airway responses to neurokinin A in normal humans in vivo. Am Rev Respir Dis 1992; 145: 12751280.

18. Maggi CA. Tachykinin receptors and airway pathophysiology. Eur Respir J 1993; 6: 735-742.

19. Adcock IM, Peters M, Gelder C, Shirasaki H, Brown CR, Barnes PJ. Increased tachykinin receptor gene expression in asthmatic lung and its modulation by steroids. $J \mathrm{Mol}$ Endocrinol 1993; 11: 1-7.

20. Bai TR, Zhou D, Weir T, et al. Substance P (NK1)- and neurokinin A (NK2)-receptor gene expression in inflammatory airway diseases. Am J Physiol 1995; 269; L309L317.

21. Naline E, Devillier P, Drapeau G, et al. Characterization of neurokinin effects and receptor selectivity in human isolated bronchi. Am Rev Respir Dis 1989; 140: 679686.

22. Advenier C, Naline E, Toty L, et al. Effects on the isolated human bronchus of SR 48968, a potent and selective nonpeptide antagonist of the neurokinin A (NK2) receptors. Am Rev Respir Dis 1992; 146: 1177-1181.

23. Ellis JL, Undem BJ, Kays JS, Ghanekar SV, Barthlow HG, Buckner CK. Pharmacological examination of receptors mediating contractile responses to tachykinins in airways isolated from human, guinea pig and hamster. $J$ Pharmacol Exp Ther 1993; 267: 95-101.

24. Chitano P, Di Blasi P, Lucchini RE, et al. The effects of toluene diisocyanate and of capsaicin on human bronchial smooth muscle in vitro. Eur J Pharmacol Environ Toxicol Pharmacol 1994; 270: 167-173.

25. Naline E, Molimard M, Regoli D, Emonds-Alt X, Bellamy JF, Advenier C. Evidence for functional tachykinin NK1 receptors on human isolated small bronchi. Am $J$ Physiol 1996; 271: L763-L767.

26. Emonds-Alt X, Vilain P, Goulaouic P, et al. A potent and selective non-peptide antagonist of the neurokinin A (NK2) receptor. Life Sci 1992; 50: PL101-PL106.

27. American Thoracic Society. Standards for the diagnosis and care of patients with chronic obstructive pulmonary disease (COPD) and asthma. Am Rev Respir Dis 1987; 136: 225-244.

28. Cockcroft DW, Killian DN, Mellon JJA, Hargreave FE. Bronchial reactivity to inhaled histamine: a method and clinical survey. Clin Allergy 1977; 7: 235-243.

29. Bel EH, Van Der Veen H, Kramps JA, Dijkman JH, Sterk PJ. Maximal airway narrowing to inhaled leukotriene $\mathrm{D}_{4}$ in normal subjects. Am Rev Respir Dis 1987; 136: 979984.

30. Joos GF, Kips JC, Pauwels RA. In vivo characterization of the tachykinin receptors involved in the direct and indirect bronchoconstrictor effect of tachykinins in two inbred rat strains. Am J Respir Crit Care Med 1994; 149: 1160-1166.

31. Emonds-Alt X, Proietto V, Van Broeck D, et al. Pharmacological profile and chemical synthesis of SR 48968, a non-peptide antagonist of the neurokinin A (NK2) receptor. Bioorg Med Chem Lett 1993; 3: 925-930.

32. Emonds-Alt X, Advenier C, Soubrié P, Le Fur G, Brelière JC. SR 48968: nonpeptide antagonist of the tachykinin NK2 receptor. Drugs Fut 1995; 20: 701-707.

33. Maggi CA, Patacchini R, Rovero P, Santicioli P. Tachykinin receptors and noncholinergic bronchoconstriction in the guinea-pig isolated bronchi. Am Rev Respir Dis 1991; 144: 363-367.

34. Pauwels R, Joos G, Van Der Straeten M. Bronchial hyperresponsiveness is not bronchial asthma. Clin Allergy 1988; 18: 317-321.

35. Joos GF, Germonpre PR, Kips JC, Peleman RA, Pauwels RA. Sensory neuropeptides and the human lower airways: present state and future directions. Eur Respir $J$ 1994; 7: 1161-1171.

36. Ichinose $\mathrm{M}$, Nakajima $\mathrm{N}$, Takahashi $\mathrm{T}$, Yamauchi $\mathrm{H}$, Inoue $\mathrm{H}$, Takishima $\mathrm{T}$. Protection against bradykinininduced bronchoconstriction in asthmatic patients by neurokinin receptor antagonist. Lancet 1992; 340: 1248-1251.

37. Schmidt D, Jörres RA, Rabe KF, Magnussen H. Reproducibility of airway response to inhaled bradykinin and effect of the neurokinin receptor antagonist FK-224 in asthmatic subjects. Eur J Clin Pharmacol 1996; 50: 269-273.

38. Joos GF, Van Schoor J, Kips JC, Pauwels RA. The effect of inhaled FK224, a tachykinin NK-1 and NK-2 receptor antagonist, on neurokinin A-induced bronchoconstriction in asthmatics. Am J Respir Crit Care Med 1996; 153: 1781-1784.

39. Ichinose M, Miura M, Yamauchi H, et al. A neurokinin 1receptor antagonist improves exercise-induced airway narrowing in asthmatic patients. Am J Respir Crit Care Med 1996; 153: 936-941.

40. Fahy JV, Wong HH, Geppetti P, et al. Effect of an NK1 receptor antagonist (CP-99,994) on hypertonic salineinduced bronchoconstriction and cough in male asthmatic subjects. Am J Respir Crit Care Med 1995; 152: 879-884.

41. Advenier C, Lagente V, Boichot E. The role of tachykinin receptor antagonists in the prevention of bronchial hyperresponsiveness, airway inflammation and cough. Eur Respir J 1997; 10: 1892-1906. 